\title{
The Relationship of Distributed Leadership and Professional Learning Community
}

\author{
Mohd Izham Mohd Hamzah1, Mohd Fadzil Jamil ${ }^{2 *}$ \\ ${ }^{1}$ Centre of Education Leadership \& Policy, Faculty of Education, Universiti Kebangsaan Malaysia, Bangi, Selangor, Malaysia \\ ${ }^{2}$ Academic Management Sector, Educational Department of Negeri Sembilan, Seremban, Negeri Sembilan, Malaysia \\ Email: izham@ukm.edu.my, ^drwnacs@gmail.com
}

How to cite this paper: Hamzah, M. I. M., \& Jamil, M. F. (2019). The Relationship of Distributed Leadership and Professional Learning Community. Creative Education, 10, 2730-2741.

https://doi.org/10.4236/ce.2019.1012199

Received: October 18, 2019

Accepted: November 25, 2019

Published: November 28, 2019

Copyright ( 2019 by author(s) and Scientific Research Publishing Inc. This work is licensed under the Creative Commons Attribution International License (CC BY 4.0).

http://creativecommons.org/licenses/by/4.0/

(c) (i) Open Access

\begin{abstract}
Distributed leadership offers a new thinking in transforming school's leadership. Professional learning community has been identified to have a strong influence on the teaching quality of teachers. This article examines the relationship of distributed leadership of secondary school administrators with professional learning community. The literatures suggest that distributed leadership perspective is a good alternative strategy to improve the quality of educational institutions, but empirical evidence shows the relationship of distributed leadership and professional learning community is limited. Data were collected from 592 teachers working in secondary schools in Negeri Sembilan, Malaysia. Data analysis was done based on Structural Equation Modeling using AMOS software. The study found that distributed leadership (DL) has a positive and strong correlation relationship with professional learning community (PLC), $\mathrm{r}=0.844, p<0.001$. Regression weight analysis for DL $\rightarrow$ PLC shows that regression coefficient value, $\beta=1.182$. This explains that when distributed leadership variable (DL) goes up by 1 unit, the professional learning community variable (PLC) will also go up by 1182 units. The distributed leadership (DL) exogenous variable in the regression model can significantly predict the change in the professional learning community (PLC) endogenous variable. The results show the value of variance in professional learning community (PLC) endogenous variable predicted by distributed leadership (DL) exogenous variable for DL -> PLC pathway. Estimated value $=0.835($ C.R. $=6.174, p<0.001)$ indicates that as much as $83.5 \%$ of the variance in professional learning community (PLC) variables can be predicted by the distributed leadership (DL) variable. In conclusion, a strong positive relationship was revealed between distributed leadership of secondary school administrators and professional learning community. Distributed leadership of secondary school administrators was also a significant predictor of professional learning community. Therefore, the findings of the study indicate that distributed leadership practiced by school administrators is a crit-
\end{abstract}


ical factor in establishing professional learning community at school level.

\section{Keywords}

Distributed Leadership, School Administrators, Professional Learning Community, Relationship, Structural Equation Modeling

\section{Introduction}

Challenges of the current globalization era and the challenges of making schools as a future learning organization as embedded in the Malaysia Education Development Plan 2013-2025 have urged school leaders and administrators to look for ways to make their organizations more flexible. Therefore, for the reformation of the system as a whole, the leadership aspect should be viewed as a collective rather than an individual leader's capacity (Fullan, 2010).

One type of school leadership that researchers focus on today is distributed leadership. There are various definitions for the term distributed leadership given by researchers. Distributed leadership is defined as a dynamic interaction between several leaders and their followers in performing their duties and responsibilities (Timperley, 2005). The main focus of distributed leadership is to mobilize leadership at all levels of the organization and not rely solely on a single top leadership (Harris, 2008) and distributed leadership is understood as a collective social process resulting from interactions involving multiple leaders (Uhl-Bien, 2006).

The concept of distributed leadership is not solely about the leadership of a school leader, but it is a process of leadership shaped by the daily interactions between school leaders (school administrators) and school organization members (Spillane et al., 2004). In this context, leadership tasks are accomplished through the interaction of several individual leaders (Spillane et al., 2001, 2004).

Leadership factors are important in determining school success because the burden of responsibility and accountability of school success and student academic achievement rests on the shoulders of school leaders (Jazzar \& Algozzine, 2007; Leithwood \& Louise, 2012). However, literatures and previous studies have found that school's principals are not directly involved in classroom activities, especially in areas where school principals are required to implement the functions of curriculum leaders such as curriculum development programs, assessment and supervision of teachers, teacher's professional development and improvement programs (Hallinger \& Murphy, 2013; James Ang \& Balasandran, 2009; Wahlstrom et al., 2010; Wahlstrom \& Louis, 2008; Azizul \& Mohamed Yusoff, 2017; Shafiq Aizatullah \& Mohd Izham, 2018), as a result of the routine of day-to-day management and administration (Abdullah et al., 2012; Horng et al., 2010; Kowalski, 2010).

Literatures show that the impact of principal leadership on students' academic achievement is through the actions of principal leadership that can influence the organization, teachers' motivation, teachers' job satisfaction, teachers' commit- 
ment and classroom teaching practices (Leithwood et al., 2008; Leithwood \& Louise, 2012; Marzano et al., 2005; Azian Nurizwani \& Mohd Izham, 2017; Nur Atiqhah \& Mohd Izham, 2018; Zaliza \& Mohd Izham, 2018).

In addition, the literatures have identified professional learning community (Hord, 2008, 2009) as a powerful influence on the quality of teaching of teachers. Although some researchers have suggested that the distributed leadership perspective is a good alternative strategy for improving the quality of educational institutions (Harris, 2003; Harris \& Spillane, 2008; Mascall et al., 2009), the empirical evidence showing the relationship and the association of distributed leadership with professional learning community is limited. Therefore, research that would provide evidence that distributed leadership has a significant relationship with professional learning community will further reinforce the relevance of both distributed leadership and professional learning community in todays' school environment.

\subsection{Distributed Leadership Model by Hulpia, Devos and Van Keer (2009)}

The Distributed Leadership Model by Hulpia, Devos and Van Keer (2009) has adopted the distributed leadership theory framework by Spillane and Diamond (2007) and distributed leadership theory by Gronn (2002) as the basis for the model. The Distributed Leadership Model developed by Hulpia, Devos and Van Keer (2009) states that distributed leadership comprises of three main dimensions:

1) Distribution of leadership functions.

2) Team Leadership.

3) Teachers' participation in decision making.

\subsection{Professional Learning Community}

The professional learning community is defined in five dimensions; 1) shared and supportive leadership, 2) shared values, goals, mission and vision, 3) collective learning and application, 4) sharing of personal practice and, 5) supportive conditions (Hord, 2004).

\section{Research Questions}

The researcher wishes to find the answers to the following research questions:

1) What is the level of distributed leadership and profesional learning community? 2) Does distributed leadership of school administrators has a significant correlation with profesional learning community? and, 3) Does distributed leadership of school administrators have a significant effect on profesional learning community?

\section{Research Hypotheses}

Based on the research questions, two hypotheses have been detailed:

1) Ho1: The correlation relation between distributed leadership and profesional learning community is significant. 
2) Ho2: The regression relation of distributed leadership on professional learning community is significant.

For Hol, the researcher wishes to investigate whether there is a strong and positive relationship exists between distributed leadership. And as for Ho2, the researcher wishes to establish whether distributed leadership has a significant effect on professional learning community.

\section{Methodology}

This quantitative research method is based on the correlational and causal relationship design using questionnaire as the main instrument for the study. The study was carried out in secondary schools in Negeri Sembilan, Malaysia. The participants for this study consisted of 960 secondary school teachers located at 60 secondary schools in the province of Negeri Sembilan, Malaysia.

To address the research questions and hypotheses, data were collected using the main instrument of the study in which the items were adapted and modified from two existing instruments; Distributed Leadership Inventory (DLI) developed by Hulpia (2009), and the School Professional Staff as Learning Community Questionnaire (SPSLC) instrument by Shirley Hord (1996).

Structural Equation Modeling (SEM) method with the help of AMOS software was used for the data analysis. Covariance and correlational analysis were carried out to determine the correlational relationship. Regression weight analysis was carried out to explore whether a significant relationship exists between distributed leadership and profesional learning community. Variance analysis was used to determine whether distributed leadership significantly able to predict changes in profesional learning community. Whereas, squared multiple correlations test was carried out to determine how much the variance in profesional learning community can be predicted by distributed leadership in the regression model.

\section{Findings and Discussions}

The first objective is to determine the level of distributed leadership and professional learning community. The overall results for the level of distributed leadership and profesional learning community are presented in Table 1.

Table 1. Descriptive statistics of distributed leadership and profesional learning community.

\begin{tabular}{lccc}
\hline \multicolumn{1}{c}{ Variable } & Mean & SD & Interpretation \\
\hline Distributed leadership & 4.19 & $\mathbf{0 . 6 4 0}$ & High \\
1) The Distribution of leadership functions & 4.19 & 0.638 & High \\
2) Team Leadership & 4.35 & 0.620 & Very High \\
3) Teachers' participation in decision making & 4.04 & 0.662 & High \\
Profesional learning community & 4.10 & 0.563 & High \\
1) Shared and supportive leadership & 4.02 & 0.624 & High \\
2) Shared values, goals, mission and vision & 4.11 & 0.523 & High \\
3) Collective learning and application & 4.17 & 0.552 & High \\
4) Sharing of personal practice and & 4.13 & 0.535 & High \\
5) Supportive conditions & 4.06 & 0.580 & High \\
\hline
\end{tabular}


From Table 1, the level of distributed leadership is high at mean $=4.19, \mathrm{~S} . \mathrm{D}=$ 0.640. Referring to Table 1, it is clear that every dimension in the Distributed Leadership construct is also at a high level. The most significant dimensions were the Team Leadership (mean $=4.35, \mathrm{~S} . \mathrm{D}=0.620$ ), followed by the Distribution of Leadership Function (mean $=4.19$, S.D $=0.638$ ) and, Teachers' Participation Dimensions in decision making (mean $=4.04$, S.D $=0.622$ ). The findings show that on average the level of Distributed Leadership by the secondary school administrators in Negeri Sembilan is high.

Table 1 shows that the average level of the Professional Learning Community is high, mean $=4.10$, S.D $=0.563$. Referring to Table 1 , it shows that every dimension in the Professional Learning Community is at a high level. The highest dimension was Collective Learning and Application (mean $=4.17$, S.D $=0.552$ ), followed by Sharing of personel practice $($ mean $=4.13$, S.D $=0.535)$, Shared values, goals, mission and vision (mean $=4.11, \mathrm{~S} . \mathrm{D}=0.523$ ), Supportive conditions (mean $=4.06, \mathrm{~S} . \mathrm{D}=0.580)$ and, Shared and supportive leadership (mean $=4.02$, S.D $=0.624)$. This finding shows that on average, the Professional Learning Community is at a high and good level. Overall, these results show that both distributed leadership and professional learning community are at high level in secondary school in Negeri Sembilan, Malaysia.

\section{Hol testing}

Ho1: The correlation relation between distributed leadership and profesional learning community is significant (Table 2).

The results of the covariance analysis indicate that the two-way relationship between the DL and PLC variables is significant. Critical Ratio, CR (critical ratio) values that are outside the range of \pm 1.96 ( $\mathrm{DL}<->$ PLC: estimates $=0.087$, $\mathrm{CR}=8.613, p<0.001)$ suggest that the relationship between the exogenous variables of the DL and PLC exogenous variables exists in the study data and was significant at $p<0.001$. Based on this finding, it can be concluded significantly that both distributed leadership (DL) and professional learning community (PLC) are influencing each other.

Table 3 shows the correlation analysis between distributed leadership (DL) and professional learning community (PLC).

The correlation analysis results in Table 3 shows the estimated correlation coefficient between DL and PLC, $r=0.844$. The result of this correlation analysis shows that distributed leadership (DL) construct has a strong positive relationship $(r=0.844, p<0.001)$ with professional learning communities (PLC) construct. This strong and positive relationship between distributed leadership and profesional learning community is significant at $p<0.001$.

Table 2. Covariance analysis between distributed leadership (DL) and professional learning community (PLC).

\begin{tabular}{ccccc}
\hline & Estimates & S.E & C.R & $p$ \\
\hline DL <--> PLC & 0.087 & 0.010 & 8.613 & $* * *$ \\
\hline
\end{tabular}

$\star * *$ indicate a highly significant at $<0.001$. 


\section{Conclusion on Hol testing}

Based on the results of the covariance analysis (estimates $=0.087, \mathrm{CR}=8.613$, $p<0.001)$ and the correlation coefficients $(\mathrm{r}=0.884, p<0.001)$, the researcher accepted Hol and reporting that distributed leadership (DL) construct has a significant positive relationship with professional learning community (PLC).

\section{Ho2 Testing}

Ho2: The regression relation of distributed leadership on professional learning community is significant.

Table 4 shows the results of regression weights analysis of distributed leadership (DL) on professional learning community (PLC).

The results of the maximum likelihood estimates analysis show that the critical ratio, C.R value of the standard regression coefficient between the distributed leadership (DL) variable and profesional learning community (PLC) variable with their indicator variables is significant. For the DL $->$ PLC path, the value of C.R. $=10.284$ and regression coefficient values $(\beta=1.182)$ indicate that there is a significant relationship between the two variables. (C.R. $=10.284, \beta=1.182, p<$ $0.001)$. Regression weight analysis for DL $>>$ PLC, shows that regression coefficient value, $\beta=1.182$. This explains that when distributed leadership variable (DL) goes up by 1 unit, the profesional learning community variable (PLC) will also goes up by 1182 units. The value of C.R. $=10.284$ shows that the probability of getting a Critical ratio, C.R of 10.284 in absolute value is less than 0.001. It shows that the regression weighting for distributed leadership (DL) in the prediction of professional learning community (PLC) is significantly different from zero at the 0.001 level (two-tailed). In other words, the research hypothesis is supported and the researcher reported that the regression relation of distributed leadership on professional learning community is significant.

Table 5 shows the variance analysis and Table 6 shows the squared multiple correlations analysis.

Table 3. Correlation coefficient test between distributed leadership (DL) and professional learning community (PLC).

\begin{tabular}{cc}
\hline & Estimate \\
\hline $\mathrm{DL}<->$ PLC & 0.844 \\
\hline
\end{tabular}

Table 4. Analysis of regression weights for Ho2 testing.

\begin{tabular}{ccccccc}
\hline & $\begin{array}{c}\text { Estimates: } \\
\text { (The Actual Beta Values) }\end{array}$ & Standard Error S.E. & Critical Ratio C.R. & $P$ & Result \\
\hline DL $>$ PLC & 1.182 & 0.115 & 10.284 & $* * *$ & Significant \\
\hline
\end{tabular}

$* * *$ indicate a highly significant at $<0.001$.

Table 5. Variance analysis.

\begin{tabular}{ccccc}
\hline & Estimates & S.E. & C.R. & P \\
\hline DL & 0.081 & 0.013 & 6.174 & $* * *$ \\
\hline
\end{tabular}

$* * *$ indicate a highly significant at $<0.001$. 
Table 6. Squared multiple correlations analysis.

\begin{tabular}{cc}
\hline & Estimates \\
\hline PLC & 0.835 \\
\hline
\end{tabular}

The results of Table 5 show the estimated value of variance, (variance estimates) $\mathrm{DL}=0.081$ is significant (S.E. $=0.013$, C.R. $=6.174, p<0.001)$. It is found that the value of C.R. is larger than \pm 1.96 . This indicates that the distributed leadership (DL) exogenous variable in the regression model can significantly predict the change in the profesional learning community (PLC) endogenous variable. The results of Table 6 show the value of variance in profesional learning community (PLC) endogenous variable predicted by distributed leadership (DL) exogenous variable for DL $->$ PLC pathway. Estimated value = 0.835 (C.R. $=6.174, p<0.001$ ) indicates that as much as $83.5 \%$ of the variance in profesional learning community (PLC) variables can be predicted by the distributed leadership (DL) variable. This means that $16.5 \%$ of the variance in the profesional learning community (PLC) variables cannot be predicted by this regression model. This means that $16.5 \%$ of the other changes were due to other factors (zl), which were not predicted by the distributed leadership (DL) variables in this structural equation model.

\section{Conclusion on $\mathrm{Ho} 2$ testing}

The results of the maximum likelihood estimates analysis show the value of C.R. the standardized regression coefficient between distributed leadership (DL) and profesional learning community (PLC) variables was significant (C.R. = 10.284, $\beta=1.182, p<0.001$ ). The results in the variance table (Table 5) and the squared multiple correlations table (Table 6) show that significantly, the predictable variance value for the DL $->$ PLC path was $0.835 \%$ or $83.5 \%(\mathrm{CR}=$ $6.174, p<0.001)$. In this case, $83.5 \%$ of the variance in the profesional learning community (PLC) variable can be predicted by the variance in the distributed leadership (DL) variable. Based on these results, research hypothesis Ho2 is supported and the researcher reported that distributed leadership has a significant effect on profesional learning community.

The Relationship between Distributed Leadership on Professional Learn-

\section{ing Community}

The findings show that there is a significant relationship between distributed leadership and professional learning community. From Ho1, it has been concluded that distributed leadership has a strong and positive relationship with profesional learning community $(\mathrm{r}=0.884, p<0.001)$. In addition, from $\mathrm{Ho} 2$, it was concluded that distributed leadership has a significant effect on profesional learning community $(\beta=1.182$, Estimated value $=0.835$ ). The findings of this study are in line with the findings that show distributed leadership has a high impact on the formation of professional learning communities in schools (Pedersen et al. 2010). The study by Pederson et al. (2010) reported that the success of forming a professional learning community is not only aided by the practice 
of distributed leadership, but also depends on the extent to which school administrators who practice distributed leadership appears to be actively engaged with teachers to produce a good teaching session.

Overall, these findings significantly indicate that the distributed leadership has a strong relationship with professional learning community $(r=0.884, p<$ 0.001). This is because the findings indicate that any increase in the distributed leadership variables will also lead to an increase in the professional learning community variable. It is clear that the practice of distributed leadership among school administrators has the influence of enhancing the practice of the professional learning community among teachers in the school. In addition, the findings also show that the distributed leadership variable can significantly predicted changes in the variables of the professional learning community. Regression weight analysis for DL -> PLC, shows that regression coefficient value, $\beta=1.182$. This explains that when distributed leadership variable (DL) goes up by 1 unit, the profesional learning community variable (PLC) will also go up by 1182 units. Furthermore, $83.5 \%$ of the variance in the profesional learning community (PLC) variable can be predicted by the variance in the distributed leadership (DL) variable.

School administrators who practiced distributed leadership are able to enhance teachers' morale and leadership development among teachers. The findings of this study show that distributed leadership practices are helpful in forming professional learning community in schools. Establishing a strong professional learning community at school will also help to improve the morale of teachers in the school. A study conducted by Angelle and Teague (2014) shows that teachers who are given the time and opportunity by the school to share good teaching practices report on the improvement in their morale. Therefore, the findings of this study and the findings of Angelle and Teague (2014) support that distributed leadership can improve teachers morale. The leadership capacity of teachers can also be nurtured by practicing distributed leadership. This is in line with the findings of a quantitative study showing that distributed leadership can increase the morale of teachers as well as build teachers' leadership capacity in schools (Sheppard et al. 2010). Improving leadership capacity among teachers is important to ensure the continuity of school leadership that can undertake the current needs of education to ensure the future direction of education in schools.

\section{Implications}

The understanding of distributed leadership may contribute to improving teacher's quality of teaching due to its characteristics such as supporting, sharing of power, active interaction and communication between school administrators and teachers. Taking into consideration the findings in this study that; 1) distributed leadership has a strong and positive relationship with profesional learning community and 2) distributed leadership has a significant effect on profesional 
learning community, it can be said that school administrators should aim adopting distributed leadership in order to improve teacher's quality of teaching.

The results of this study may also be evaluated in terms of developing school principals and educational policies. School administrators are the front line of school leadership. They are the ones who will shape the climate as well as the direction and the mission of the school. Therefore, school administrators should be guided on how to practice distributed leadership (Harris, 2008). The findings of the strong and positive relationship between school administrators' distributed leadership and professional learning community can be used as a guide and foundation for improving school leadership.

In addition, the findings also show that distributed leadership practiced by school administrators is also a critical factor in forming professional learning community in schools. The success of establishing a strong professional learning community in the school will be a catalyst for the shared learning process among teachers focused on delivering quality teaching to their students. The literature shows that the quality of teacher teaching can be improved through the establishment of a strong Professional Learning Community in schools that ensures continuous professional learning among teachers (Hord, 2004, 2008, 2009). According to Hord (2008), most people agree that the true purpose of schools is to provide students with learning and the most important factor in determining whether or not students can learn well is through the quality of teaching by teachers. Therefore, the establishment of a strong professional learning community in the school will ensure quality teaching by the teachers.

The results of this study are limited to the opinions of teachers in secondary schools in Negeri Sembilan, Malaysia. Although this study reveals evidence that shows the positive relationship between distributed leadership and profesional learning community, the results reflect the characteristics and perceptions of the individuals working in schools where the research was conducted. For this reason, studies carried out in different places are needed for a generalization of the results obtained in this research. Hence, it is recommended that research on the relationship of distributed leadership with profesional learning community should also be carried out in different places.

\section{Conclusion}

In conclusion, the findings of this study provide a significant reflection of the contribution of distributed leadership in relation to the effect on teacher capacity factor in schools namely professional learning community. The findings of the study show that; 1) distributed leadership significantly has a strong and positive relationship with profesional learning community and, 2) distributed leadership has a significant effect on profesional learning community. Thus, this study shows that distributed leadership is significantly related to profesional learning community. Therefore, the researchers conclude that the distributed leadership aspect is a significant factor in driving the school towards excellence. 


\section{Acknowledgements}

The researchers would like to acknowledge the Ministry of Higher Education (MOHE) for the financial funding of this research through Fundamental Research Grant Scheme (FRGS) [Code: FRGS/1/2016/SSI09/UKM/02/9], Research Grant FPEND 1 (GG-2019-031) and PP-FPEND-2019.

\section{Conflicts of Interest}

The authors declare no conflicts of interest regarding the publication of this paper.

\section{References}

Abdullah, M. Y., Zain, S., Mohamad, B., Ambotang, A. S., Taat, M. S., \& Talip, R. (2012). Kepimpinan Instruksional Pengetua: Cabaran Dan Harapan. Utusan Borneo B4.

Angelle, P. S., \& Teague, G. M. (2014). Teacher Leadership and Collective Efficacy: Teacher Perceptions in Three US School Districts. Journal of Educational Administration, 52, 738-753. https://doi.org/10.1108/JEA-02-2013-0020

Azian Nurizwani, S. S., \& Mohd Izham, M. H. (2017). Amalan kepimpinan tersebar guru besar dan hubungannya dengan kepuasan kerja guru di SABK rendah jenis kluster di Sarawak. In The Seminar Penyelidikan Pendidikan Kebangsaan (pp. 486-502). Selangor: UKM.

Azizul, A., \& Mohamed Yusoff, M. N. (2017). Amalan kepimpinan distributif guru besar dan hubungannya dengan komitmen organisasi guru. In The Seminar Penyelidikan Pendidikan Kebangsaan (pp. 247-256). Selangor: UKM.

Fullan, M. (2010). All Systems Go: The Change Imperative for Whole System Reform. Thousand Oaks, CA: Corwin Press.

Gronn, P. (2002). Distributed Leadership. In K. Dlm. Leithwood, \& P. Hallinger (Eds.), Second International Handbook of Educational Leadership and Administration (pp. 653-696). Dordrecht: Kluwer Academic Publisher. https://doi.org/10.1007/978-94-010-0375-9 23

Hallinger, P., \& Murphy, J. F. (2013). Running on Empty? Finding the Time and Capacity to Lead Learning. NASSP Bulletin, 97, 5-21. https://doi.org/10.1177/0192636512469288

Harris, A. (2003). Teacher Leadership as Distributed Leadership: Heresy, Fantasy or Possibility? School leadership \& management, 23, 313-324. https://doi.org/10.1080/1363243032000112801

Harris, A. (2008). Distributed Leadership: According to the Evidence. Journal of Educational Administration, 46, 172-188. https://doi.org/10.1108/09578230810863253

Harris, A., \& Spillane, J. (2008). Distributed Leadership through the Looking Glass. Management in Education, 22, 31. https://doi.org/10.1177/0892020607085623

Hord, S. E. (2004). Learning Together: Leading Together. Changing Schools through Plcs. New York: Teachers College Press.

Hord, S. M. (2008). Evolution of the Professional Learning Community. National Staff Development Council, 29, 10-13.

Hord, S. M. (2009). Professional Learning Communities. National Staff Development Council, 30, 40-43.

Horng, E. L., Klasik, D., \& Loeb, S. (2010). Principal's Time Use and School Effectiveness. American Journal of Education, 116, 491-523. https://doi.org/10.1086/653625 
Hulpia, H., Devos, G., \& Van Keer, H. (2009). The Influence of Distributed Leadership on Teachers' Organizational Commitment: A Multilevel Approach. The Journal of Educational Research, 103, 40-52. https://doi.org/10.1080/00220670903231201

James Ang, J. E., \& Balasandran, R. (2009). Kepimpinan Instruksional. Satu Panduan Praktikal. Kuala Lumpur: PTS Professional.

Jazzar, M., \& Algozzine, B. (2007). Keys to Successful 21st Century: Educational Leadership. London: Pearson Education, Inc.

Kowalski, T. J. (2010). The School Principal. Visionary Leadership and Competent Management. New York: Routledge Taylor and Francis Group. https://doi.org/10.4324/9780203857397

Leithwood, K., \& Louise, K. S. (2012). Linking Leadership to Student Learning. San Francisco, CA: Jossey-Bass.

Leithwood, K., Harris, A., \& Hopkins, D. (2008). Seven Strong Claims about Successful School Leadership. School Leadership and Management, 28, 27-42. https://doi.org/10.1080/13632430701800060

Marzano, R. J., Waters, T., \& Mcnulty, B. A. (2005). School Leadership That Works: From Research to Results. ERIC.

Mascall, B., Leithwood, K., Strauss, T., \& Sacks, R. (2009). The Relationship between Distributed Leadership and Teacher's Academic Optimism. In A. Dlm. Harris (Ed.), Distributed Leadership: Different Perspectives (pp. 81-100). London: Springer. https://doi.org/10.1007/978-1-4020-9737-9 5

Nur Atiqhah, A., \& Mohd Izham, M. H. (2018). Amalan kepimpinan distributif guru besar dan motivasi guru. In The International Conference on Global Education VI (pp. 2096-2108). Bangi: Penerbit UKM.

Shafiq Aizatullah, S., \& Mohd Izham, M. H. (2018). Amalan pengurusa kokurikulum dan komitmen terhadap tugas pengurus kokurikulum sekolah. In The International Conference on Global Education VI(pp. 2126-2135). Bangi: Penerbit UKM.

Spillane, J. P., Halverson, R., \& Diamond, J. B. (2001). Investigating School Leadership Practice: A Distributed Perspective. Educational Researcher, 30, 23-28. https://doi.org/10.3102/0013189X030003023

Spillane, J. P., Halverson, R., \& Diamond, J. B. (2004). Towards a Theory of Leadership Practice: A Distributed Perspective. Journal of Curriculum Studies, 36, 3-34. https://doi.org/10.1080/0022027032000106726

Spillane, J., \& Diamond, J. (2007). Taking a Distributed Perspective. In J. Dlm. Spillane, \& J. Diamond (Eds.), Distributed Leadership in Practice (pp. 1-15). New York: Teachers College.

Timperley, H. S. (2005). Distributed Leadership: Developing Theory from Practice. Journal of Curriculum Studies, 37, 395-420. https://doi.org/10.1080/00220270500038545

Uhl-Bien, M. (2006). Relational Leadership Theory: Exploring the Social Processes of Leadership and Organizing. The Leadership Quarterly, 17, 654-676. https://doi.org/10.1016/j.leaqua.2006.10.007

Wahlstrom, K. L., \& Louis, K. S. (2008). How Teachers Experience Principal Leadership: The Roles of Professional Community, Trust, Efficacy, and Shared Responsibility. Educational Administration Quarterly, 44, 458-495. https://doi.org/10.1177/0013161X08321502

Wahlstrom, K., Louis, K., Leithwood, K., \& Anderson, S. (2010). Investigating the Links to Improved Student Learning: Executive Summary of Research Findings. 
http://www.wallacefoundation.org

Zaliza, M. Y., \& Mohd Izham, M. H. (2018). Amalan kepimpinan instruksional pengetua dan hubungannya dengan komitmen guru di sekolah menengah Daerah Seremban, Negeri Sembilan. In The Proceeding International Conference on Global Education VI (Vol. 2, pp. 2171-2183). 